\title{
The Effects of Anxiety and Emotional Intelligence on The Mathematic Learning Outcomes of Fifth Grade Students
}

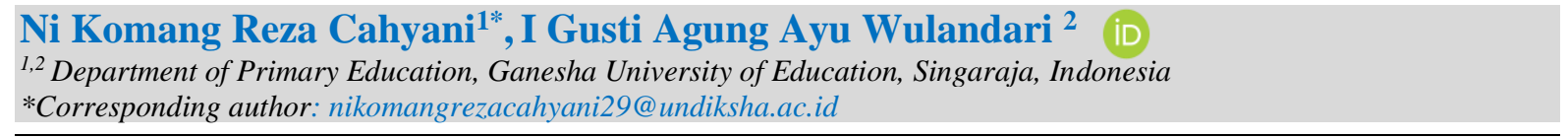

\section{Abstrak}

Siswa mengalami kecemasan yang sangat tinggi sehingga berdampak pada susahnya mencerna dan memahami materi pembelajaran Matematika. Hal ini menyebabkan hasil belajar Matematika rendah. Penelitian ini bertujuan untuk menganalisis pengaruh kecemasan dan kecerdasan emosional terhadap hasil belajar Matematika siswa kelas $V$ sekolah dasar. Penelitian ini merupakan penelitian "ex post facto" dengan jumlah populasi sebanyak 238 siswa. Sampel ditentukan menggunakan teknik proporsional random sampling, sehingga didapatkan jumlah sampel sebanyak 142 siswa. Teknik yang digunakan untuk mengumpulkan data yaitu observasi, wawancara, kuesioner, pencatatan dokumen, dan tes. Instrument yang digunakan untuk mengumpulkan data yaitu kuesioner. Uji hipotesis dilakukan dengan teknik analisis regresi sederhana dan analisis regresi ganda. Hasil penelitian ini menunjukkan bahwa: Terdapat pengaruh kecemasan terhadap hasil belajar matematika dengan kontribusi sebesar 3,5\%; Terdapat pengaruh kecerdasan emosional terhadap hasil belajar matematika dengan kontribusi sebesar 6,6\%; Terdapat pengaruh kecemasan dan kecerdasan emosional terhadap hasil belajar matematika dengan kontribusi sebesar 7,2\%. Sehingga kesimpulan hasil penelitian menunjukkan terdapat pengaruh yang signifikan antara kecemasan dan kecerdasan emosional terhadap hasil belajar Matematika siswa kelas $V$ sekolah dasar.

Kata kunci: Kecemasan, Kecerdasan Emosional, Hasil Belajar Matematika

\section{Abstract}

Students experience very high anxiety, so it impacts the difficulty of digesting and understanding mathematics learning materials. It causes low Mathematics learning outcomes. This study analyzes the effect of anxiety and emotional intelligence on fifth-grade elementary school students' mathematics learning outcomes. This study was an "ex post facto" study with a population of 238 students. The sample was determined using a proportional random sampling technique to obtain a total sample of 142 students. The techniques used to collect data were observation, interviews, questionnaires, document recording, and tests. The instrument used to collect data was a questionnaire. Hypothesis testing was carried out using simple regression analysis techniques and multiple regression analysis. The results of this study indicate that: There is an influence of anxiety on mathematics learning outcomes with a contribution of $3.5 \%$; There is an influence of emotional intelligence on mathematics learning outcomes with a contribution of $6.6 \%$; There is an influence of anxiety and emotional intelligence on mathematics learning outcomes with a contribution of $7.2 \%$. So the conclusion of the research shows a significant influence between anxiety and emotional intelligence on the mathematics learning outcomes of fifth-grade elementary school students.

Keywords: Anxiety, Emotional Intelligence, Mathematic Learning Outcomes

\begin{tabular}{|c|c|}
\hline History: & Publisher: Undiksha Press \\
\hline Received : February 12, 2021 & Licensed: This work is licensed under \\
\hline Revised : March 15, 2021 & a Creative Commons Attribution 3.0 License \\
\hline Accepted : April 02, 2021 & (क) (0) \\
\hline Published : April 25, 2021 & $D_{E Y}$ SA $^{2}$ \\
\hline
\end{tabular}

\section{Introduction}

Mathematics plays an important role in everyday life, such as counting and measuring activities. Mathematics is a compulsory subject at every level of education that needs to be given to students to think critically, logically, and analytically (Dara Asshofi \& Damayani, 2019; Mulasari, Wulandari, 2020). People use some basic number operations, namely addition, subtraction, multiplication, and division. Mathematics is one component of a series of subjects that have an important role in education. Mathematics is knowledge obtained from thinking activities formed from the results of practical human experience (Gunantara, Suarjana, \& Riastini, 2014; Laily, Jalal, \& Karnadi, 2019). Mathematics is basic knowledge 
related to patterns and formations always presented from small concepts related to calculations in daily activities. Mathematics should be given to all students starting from elementary school to equip students with the ability to think logically, analytically, systematically, critically, and creatively, as well as the ability to work together (Anggreni, Wiarta, \& Putra, 2020; Ayulina, Ngurah, \& Agustika, 2020). In this case, educators play an important role. Apart from being facilitators, mentors, educators also play a role in creating a pleasant learning atmosphere to positively impact achieving learning outcomes (Wulandari \& Agustika, 2018). It is necessary to create a conducive learning atmosphere, especially for elementary school students, to achieve learning objectives by applying various learning designs. Learning objectives can be met, namely from the achievement of learning outcomes in each material, one of which is learning mathematics (Amir, Rendani, Nainggolan, \& Jannah, 2018).

The main view that Mathematics is a difficult subject that causes anxiety for students in learning mathematics. Mathematics is a subject that is difficult to understand and is considered unattractive. Students have been overcome with fear during the learning process, which causes difficulty in concentration (Juliyanti \& Pujiastuti, 2017; Nisrina, Ajeng, 2018). It becomes a discrepancy and affects the learning outcomes of mathematics. Based on the recorded documents obtained from initial observations made on fifth-grade students in the Ir. SD Soekarno South Denpasar and interviews with several students and homeroom teachers regarding learning outcomes in mathematics found that of the 84 fifth grade students at SD Negeri 5 Pedungan, 57 considered Mathematics a difficult subject to understand and from 3 schools in the Ir. SD Soekarno, as many as 127 students, scored below the KKM. There are internal and external factors that can affect student learning outcomes. Mathematics learning outcomes are the results of students' abilities in Mathematics obtained from experience and practice during the teaching and learning process, which are students' abilities in Mathematics subjects based on the Mathematics scores obtained and students' ability to solve mathematical problems. Basic knowledge of Mathematics is a determining factor in students' ability to explore the next material (Anisa et al, 2019; Supardi, 2010). Anxiety is a common reaction during Mathematics learning. Symptoms caused are feelings of worry, fear, and tension in dealing with math problems or in carrying out math learning (Aspriyani, 2020; Hidayati, 2012).

An emotional state of insecurity in a person characterized by fear, worry, insecurity, and tension is sometimes experienced at different levels. Anxiety is a familiar feeling in general, where a person feels afraid or loses confidence for unknown reasons (Bakhri, Sari, \& Ernawati, 2019; Lisma, Rahmadhani, \& Siregar, 2019). The characteristics of anxiety are panic, irritability, difficulty concentrating, tension, worry, lack of confidence, excessive sweating, frequent shaking, and nausea. Anxiety can positively impact when it remains normal and controlled by physical and intellectual performance, making students more prepared for the mathematics learning process because anxiety encourages students to be more prepared. Otherwise, it will be detrimental to the student when the anxiety is excessive and uncontrollable, including the student's mathematics learning outcomes. Previous research also stated anxiety on students' mathematics learning outcomes (Nurrahmi, Witri, \& Syahrilfuddin, 2019). Student endurance in dealing with anxiety is influenced by the ability to control emotions. Associated with emotions, there is a term called emotional intelligence. The view of most people is that to get high learning outcomes, a child only has to have high intellectual intelligence (IQ). Whereas many other things that can affect student learning outcomes, one of which is emotional intelligence. Intellectual intelligence (IQ) only contributes $20 \%$ to success, while $80 \%$ contributes to other strengths, including emotional intelligence (Goleman, 2015). Emotional intelligence is a subset of social intelligence that involves monitoring the social feelings that affect other people's strengths, sorting things out, 
and using this information to guide thoughts and actions. Emotional intelligence is the intelligence possessed by each individual in controlling emotions.

Not everyone can respond to their emotional tendencies (Arieska, Syafri, \& Zubaedi, 2018). Low emotional intelligence will be difficult to focus (concentration) during the teaching and learning process, causing low student learning outcomes. Students with high emotional intelligence will be more skilled in calming down and understanding the subject matter. On the contrary, if students have low emotional intelligence, they cannot focus their attention (Mirnawati \& Basri, 2018). And can not understand the material well, so it has an impact on learning outcomes. Students who have high emotional intelligence tend to solve problems well (Nurfitriyanti, 2017; Supriyanto, 2021). Because students tend to recognize, understand and manage a problem so that they can solve it appropriately. Emotional intelligence in learning mathematics is needed to create motivation and eliminate pessimism, which leads to enthusiasm, perseverance, and patience. The difference in the results of previous research states a positive relationship between emotional intelligence and learning achievement in Mathematics with a contribution of 33.64\% (Nisrina, Rini, \& Latifah, 2018). Other research states no significant effect of emotional intelligence on fifth-grade students' learning outcomes (Munirah \& Ahmad Putri, 2018). It is still unknown whether there is an influence of emotional intelligence on mathematics learning outcomes in fifth-grade students in the Ir. Soekarno Elementary School, South Denpasar. Based on the description above, this study aims to analyze the effect of anxiety and emotional intelligence on the mathematics learning outcomes of fifth-grade elementary school students. It is hoped that this research can help students in overcoming mathematics learning anxiety.

\section{Methods}

This type of research was ex post facto. Ex post facto research is an approach to research subjects to examine what the research subjects have reasonably without any deliberate effort to provide treatment to bring up the variables under study. Ex post facto begins by describing the current condition, which is used as a cause and effect of assumptions and influences the changes. Based on this description, this research is classified as ex post facto research because the researcher does not treat the variables studied. This study contains two independent variables, namely anxiety (X1) and emotional intelligence (X2), and one dependent variable, namely learning outcomes of mathematics. The location of the research was carried out in the Ir. Soekarno Elementary School, South Denpasar. The population used in this study were all fifth-grade students at Ir. Soekarno Elementary School, South Denpasar Class of 2020/2021. Based on the data obtained, a population of 238 students. The proportional random sampling technique takes samples, and to determine the example can be seen in Isaac and Michael's table. In this study, the error rate used is an error rate of 5\%. The total population of fifth-grade students in the Ir. SD Soekarno South Denpasar as many as 238 students, samples were taken with an error rate of 5\% were 142 students. The data collection method used is a non-test method. The non-test technique used in this research is document recording and questionnaires. Data on mathematics learning outcomes were obtained through document recording, while anxiety and emotional intelligence were obtained through questionnaires. Anxiety and emotional intelligence questionnaires each consist of 25 statements with alternative answers to this questionnaire referring to a Likert scale with a score range of 1-4.

The data analysis method used in this study was inferential statistical analysis. The inferential statistical analysis method is a statistical technique used to analyze a sample of data, and the results are applied to the population. The data analysis technique used in this research is the simple regression analysis technique and multiple regression analysis techniques. Before testing the research hypothesis, it is necessary first to test the prerequisite 
analysis, including the normality test, linearity test, multicollinearity test, and heteroscedasticity test. After the prerequisite test is met, then the hypothesis test is carried out. The first and second hypothesis testing uses simple linear regression, while the hypothesis testing uses multiple linear regression.

\section{Results and Discussion}

This study uses the first and second hypothesis testing using simple linear regression and multiple linear regression. Before analyzing the simple linear regression test and the multiple linear regression test, the requirements must first be carried out. The analysis prerequisite test consisted of normality test, linearity test, multicollinearity test, and heteroscedasticity test. The normality test was conducted to determine whether the data were normally distributed or not. Based on calculations using the Kolmogorov-Smirnov formula in Microsoft Excel. Maximum residual normality test requirements < Kolmogorov-Smirnov table, so that the data can be normally distributed. More details are presented in Table 1.

Table 1. Residual Normality Test Results

\begin{tabular}{lccc}
\hline \multicolumn{1}{c}{ Variable } & $\left|\mathbf{F}_{\mathbf{t}}-\mathbf{F s}\right| \mathbf{M a x}$ & Ks Table & Conclusion \\
\hline $\begin{array}{l}\text { Anxiety towards Mathematics } \\
\text { Learning Outcomes (X1Y) }\end{array}$ & 0.074 & 0.113 & $\begin{array}{c}\text { Normally Distributed } \\
\text { Data }\end{array}$ \\
$\begin{array}{l}\text { Emotional Intelligence on } \\
\text { Mathematic Learning }\end{array}$ & 0.048 & 0.113 & $\begin{array}{c}\text { Normally Distributed } \\
\text { Data }\end{array}$ \\
$\begin{array}{l}\text { Outcomes (X2Y) } \\
\text { Anxiety and Emotional }\end{array}$ & & & Normally Distributed \\
Intelligence on Mathematic & 0.039 & 0.113 & Data \\
Learning Outcomes (X1X2Y) & & & \\
\hline
\end{tabular}

The Table 1 shows that the maximum residual score of anxiety data on Mathematics Learning Outcomes is $0.074<0.113$, which means that the residual data is usually distributed because the score of $|\mathrm{Ft} \mathrm{Fs}|$ Max Table < Ks. The maximum score of emotional intelligence residual data on Mathematics Learning Outcomes is $0.048<0.113$, which means the residual data is normally distributed. The maximum score of residual data on anxiety and emotional intelligence in Mathematics Learning Outcomes is $0.039<0.113$, which means that the residual data has a typical distribution. It means that information on anxiety, emotional intelligence, and mathematics learning outcomes are each normally distributed. The linearity test was conducted to determine whether there was a linear relationship between the independent variable and the dependent variable or not. The criteria for testing the deviation of linearity is if the sig Deviation of Linearity is greater than the significant level, it can be concluded that the variables $\mathrm{x}$ and $\mathrm{y}$ have a linear relationship. The linearity test was carried out with the help of the SPSS 25 application program for windows. The results of the linearity test can be seen from the output of the SPSS program in Table 2.

Table 2. Linearity Test Results

\begin{tabular}{lccc}
\hline \multicolumn{1}{c}{ Variable } & $\begin{array}{c}\text { Deviation from } \\
\text { Linearity }\end{array}$ & $\begin{array}{c}\text { Significant } \\
\text { Level }\end{array}$ & Conclusion \\
\hline $\begin{array}{l}\text { Anxiety towards Mathematic Learning } \\
\begin{array}{l}\text { Outcomes (X1Y) } \\
\text { Emotional Intelligence on Mathematic }\end{array}\end{array}$ & 0,196 & 0,05 & Linear \\
Learning Outcomes (X2Y) & 0,130 & 0,05 & Linear \\
\hline
\end{tabular}


Based on the Table 2, the results of the linearity test analysis show that the Sig Deviation of linearity anxiety on mathematics learning outcomes is $0.196>$ a significant level of 0.05 , meaning that there is a linear relationship. Sig Linearity deviation of emotional intelligence on mathematics learning outcomes is $0.130>0.05$ significant level, meaning a linear relationship. The multicollinearity test was conducted to determine whether there was a relationship between the independent variables by testing the VIF score and the Tolerance score with the help of the SPSS 25 for windows application program. Regression analysis is said to be good if there is no multicollinearity. The criteria for the multicollinearity test are if the Variance Inflation Factor (VIF) $<10$ and the importance score of Collinearity Tolerance $>0.1$, it can be said that there is no multicollinearity. The results of the multicollinearity test can be seen from the SPSS 25 for the windows program in Table 3.

Table 3. Multicollinearity Test Results

\begin{tabular}{lccl}
\hline \multicolumn{1}{c}{ Variable } & Tolerance & VIF & Explanation \\
\hline Anxiety (X1) & 0,767 & 1,304 & Multicollinearity does not occur \\
Emotional Intelligence (X2) & 0,767 & 1,304 & Multicollinearity does not occur \\
\hline
\end{tabular}

Based on the Table 3, the results of the multicollinearity test show a Tolerance score of 0.767 and a VIF score of 1.304. So it can be concluded that there is no multicollinearity between independent variables. The heteroscedasticity test aims to determine whether there is an inequality of variance from the residuals in the regression model or not. The condition that must be met in the regression model is that there is no heteroscedasticity problem. With the condition that the significance score is better than the significance level $=0.05$, it can be stated that there is no heteroscedasticity problem. The linearity test was carried out with the help of the SPSS 25 windows application program. The results of the heteroscedasticity test from the output of the SPSS program are presented in Table 4.

Table 4. Heteroscedasticity Test Results

\begin{tabular}{lcc}
\hline \multicolumn{1}{c}{ Variable } & Sig & Explanation \\
\hline Anxiety (X1) & 0.904 & Heteroscedasticity does not occur \\
Emotional Intelligence (X2) & 0.707 & Heteroscedasticity does not occur \\
\hline
\end{tabular}

Based on the Table 4, the results of the heteroscedasticity test have significant scores on the anxiety and emotional intelligence variables, respectively 0.904 and $0.707>0.05$. It can be concluded that there is no heteroscedasticity in the regression model in this study. After fulfilling the analysis prerequisite test, hypothesis testing was carried out using simple linear regression analysis techniques to test the first and second hypotheses. In contrast, the technique of multiple linear regression analysis is for the third hypothesis. The hypothesis being tested is the null hypothesis (H0). The criteria for testing the hypothesis is if Freg < Ftable, then $\mathrm{H} 0$ is accepted, while if Freg > Ftable, then $\mathrm{H} 0$ is rejected. Calculation of the first hypothesis with simple regression analysis obtained a line equation, namely $\mathrm{Y}=70.232$ $+0.068 \mathrm{X} 1$ with Freg $=5.094>$ Ftable $=3.91$ which means it is significant and linear. It shows that $\mathrm{HO}$ is rejected. It can be concluded that anxiety has a significant effect on mathematics learning outcomes for fifth-grade students of Cluster Ir. Soekarno Elementary School, South Denpasar Class of 2020/2021. The regression determination coefficient equation is the score used to measure the contribution of the independent variable to the dependent variable. The coefficient of determination obtained is $\mathrm{R} 2=0.035$ with a contribution of $3.5 \%$. 
The analysis results for testing the second hypothesis with simple regression analysis obtained a line equation $\mathrm{Y}=65.796+116 \mathrm{X} 2$ with Freg $=9.837>$ Ftable $=3.91$, which means it is significant and linear. It shows that $\mathrm{HO}$ is rejected. It can be concluded that emotional intelligence has a significant effect on the mathematics learning outcomes of fifthgrade students of Cluster Ir. Soekarno Elementary School, South Denpasar Class of $2020 / 2021$. The coefficient of determination obtained from the analysis is R $2=0.066$, with a contribution of $6.6 \%$. The results of the analysis for testing the third hypothesis with multiple regression analysis obtained $\mathrm{Y}=65.02+0.031 \mathrm{X} 1+0.099 \mathrm{X} 2$ with Freg $=5.397>$ Ftable $=$ 3.06, which means significant and linear. It shows that HO is rejected. It can be concluded that anxiety and emotional intelligence significantly affect mathematics learning outcomes for fifth-grade students of Cluster Ir. Soekarno Elementary School, South Denpasar Class of $2020 / 2021$. The coefficient of determination obtained from the analysis is R2 $=0.072$, with a contribution of $7.2 \%$. Based on the results of data analysis, it can be concluded that there is a significant influence between anxiety and emotional intelligence on the mathematics learning outcomes of fifth-grade students of Cluster Ir. Soekarno Elementary School, South Denpasar Class of 2020/2021.

The process of learning mathematics requires high self-confidence, optimism, and perseverance to overcome the problems that will be faced (Amir et al., 2018; Rosmiati \& Lestari, 2021; Wulandari \& Rakhmawati, 2019). Everyone has experienced anxiety at some point in their life, and different methods deal with it. One of the efforts that can be done to improve mathematics learning outcomes is to grow and increase high emotional intelligence in students. It can be achieved by growing self-awareness of emotions, managing emotions, self-motivation, empathy, and building relationships with others. Emotional intelligence also needs to be fostered to increase enthusiasm for learning, especially in Mathematics, to achieve the expected goals (Asy'ari, Ekayati, \& Matulessy, 2014). Their anxiety and emotional intelligence affect students' success in mastering Mathematics. Anxiety is the subjective experience of mental tension, distress, and stress that accompanies a conflict or threat. However, student anxiety is not the only factor that affects learning outcomes. It needs to be addressed so that future students will no longer regard Mathematics as a scary and challenging subject that will damage students' thinking concepts and impact student learning outcomes. Some students feel motivated by anxiety because the influencing factors can positively and negatively affect students' learning outcomes tests. However, to turn anxiety into a positive thing, external help is needed, such as schools, which are teachers in directing, and friends who can support each other (Aryani \& Hasyim, 2018; Novikasari, 2017).

Controlling math anxiety can be done in several ways, such as studying every day to train students to solve math problems, using appropriate learning techniques, understanding math concepts instead of memorizing them, remembering past successes to increase selfconfidence, asking for help and guidance (Irel et al, 2018; Yaya Setiadi, 2018). If needed, practice calming down like praying before studying, taking deep breaths, or something else. To get maximum student learning outcomes, teachers also need strategies to reduce students' math anxiety. Teachers can motivate students to minimize anxiety and ensure that Mathematics is not a complicated subject and easy to learn and understand. It is hoped that it can change students' perceptions of Mathematics as a challenging subject by providing this motivation. Changes in students' perceptions of Mathematics are expected to minimize students' mathematical anxiety during the learning process, hoping that student learning outcomes will increase compared to before. On the contrary, the possibility of anxiety being positive will be smaller and lead to negative things.

Previous research states a positive relationship between anxiety and student learning outcomes (I. Nofrialdi, Maison, \& Muslim, 2018; Pamungkas, 2015). Other research findings also show that anxiety contributes to learning outcomes by $8.82 \%$, and other factors 
determine the remaining 91.8\% (Nurrahmi et al., 2019). Student endurance in dealing with anxiety is influenced by the ability to control emotions. There is a term called emotional intelligence Associated with emotions. Emotional intelligence is the ability to motivate oneself, survive frustration, control impulses, not exaggerate pleasure, regulate moods, and keep stress loads from paralyzing the ability to think, empathize, and pray. Low emotional intelligence will make it difficult to focus during the teaching and learning process, causing low student achievement (Goleman, 2015; Prafitriani et al, 2019). Other studies also show a significant relationship between emotional intelligence and mathematics learning outcomes (Asih \& Rochmah, 2019; Hamdani, Eva, \& Indra, 2012; Setyawan \& Simbolon, 2018). Emotional intelligence has an important role in the fields needed, both formal and informal, to achieve student success. Emotional intelligence in students should be a special concern for educators in the learning process. It is also supported by other research that states a joint influence between anxiety and emotional intelligence on learning outcomes (Setiadi, 2018). Based on this description, this study shows that anxiety and emotional intelligence affect mathematics learning outcomes. The higher the anxiety and emotional intelligence, the better the effect in improving mathematics learning outcomes. Anxiety that is still classified as normal and controlled can have a good impact because anxiety strengthens students' physical and intellectual performance. Students will also be better prepared to take math lessons and be able to make the right decisions. Good emotional intelligence can result in good emotional management and maximize mathematics learning outcomes.

\section{Conclusion}

Based on the results of data analysis, it can be concluded that there is a significant influence between anxiety and emotional intelligence on the mathematics learning outcomes of fifth-grade students of Cluster Ir. Soekarno Elementary School, South Denpasar Class of 2020/2021. The process of learning mathematics requires high self-confidence, optimism, and perseverance to overcome the problems that will be faced.

\section{References}

Amir, Rendani, Nainggolan, \& Jannah. (2018). Pembelajaran Kooperatif Dalam Mereduksi Kecemasan Matematis Siswa (Math Anxiety). Jurnal Prinsip Pendidikan Matematika, 1(1). https://doi.org/https://doi.org/10.33578/prinsip.v1i1.17.

Anggreni, Wiarta, \& Putra. (2020). Pengaruh Model Pembelajaran ( SAVI ) Berbasis ( TIK ) Terhadap Kompetensi Pengetahuan Matematika. Pedagogi Dan Pembelajaran, 3(1), 15-24. https://doi.org/http://dx.doi.org/10.23887/jp2.v3i1.24357.

Anisa, A., Kodirun, K., Busnawir, B., \& Rahmat, R. (2019). Pengaruh Pengetahuan Dasar Matematika Terhadap Hasil Belajar Matematika Siswa Kelas X SMA Negeri 1 Lawa. Jurnal Pendidikan Matematika, 10(1). https://doi.org/https://doi.org/10.36709/jpm.v10i1.5648.

Arieska, Syafri, \& Zubaedi, Z. (2018). Pengembangan Kecerdasan Emosional (Emotional Quotient) Daniel Goleman Pada Anak Usia Dini Dalam Tinjauan Pendidikan Islam. Al Fitrah: Journal of Early Childhood Islamic Education, 1(2). https://doi.org/https://doi.org/10.29300/alfitrah.v1i2.1337.

Aryani, T. D., \& Hasyim, M. (2018). Pengaruh Kecemasan Matematis, Problem Stres Matematika dan Self-Regulated Learning terhadap Hasil Belajar Matematika Siswa. Aksioma, 7(2), 243-252. https://doi.org/10.24127/ajpm.v7i2.1422.

Asih, T. A., \& Rochmah, E. (2019). Hubungan Kecerdasan Emosional Denganhasil Belajar Matematika Siswa Sekolah Dasar. Jurnal PGSD, 5(2). Retrieved from https://ejournal.umc.ac.id/index.php/JPS/article/view/746. 
Aspriyani, R. (2020). Self Esteem Siswa Terhadap Kemampuan Komunikasi Matematika. Jurnal Penelitian Dan Pembelajaran Matematika, 13(2). https://doi.org/http://dx.doi.org/10.30870/jppm.v13i2.8582.

Asy'ari, M., Ekayati, I. N., \& Matulessy, A. (2014). Konsep diri, Kecerdasan Emosi dan Motivasi Belajar Siswa. Persona: Jurnal Psikologi Indonesia, 3(1). https://doi.org/https://doi.org/10.30996/persona.v3i01.372.

Ayulina, Ngurah, G., \& Agustika, S. (2020). Kontribusi Konsep Diri dan Motivasi Belajar Terhadap Kompetensi Pengetahuan Matematika. Mimbar PGSD Undiksha, 8(1), 7079. https://doi.org/http://dx.doi.org/10.23887/jjpgsd.v8i1.24580.

Bakhri, S., Sari, A. F., \& Ernawati, A. (2019). Kualitas Pembelajaran Kontekstual Siswa IPS Materi Program Linier yang Memiliki Kecemasan Belajar Matematika. Kreano Jurnal Matematika Kreatif-Inovatif,

$10(2)$. https://doi.org/https://doi.org/10.15294/kreano.v10i2.19061.

Dara Asshofi, M. P., \& Damayani, A. T. (2019). Peningkatan Hasil Belajar Matematika Materi Faktor Persekutuan Besar dan Kelipatan Persekutuan Kecil melalui Model NHT Berbantu Media Papan Puzzle Berbintang. Jurnal Ilmiah Sekolah Dasar, 3(4). https://doi.org/https://doi.org/10.23887/jisd.v3i4.21881.

Goleman, D. (2015). Emotional Intelligence. Jakarta: PT Gramedia Pustaka Utama.

Gunantara, G., Suarjana, M., \& Riastini, P. N. (2014). Penerapan model pembelajaran problem based learning untuk meningkatkan kemampuan pemecahan masalah matematika siswa kelas V. Jurnal Mimbar PGSD Undiiksha, 2(1). https://doi.org/http://dx.doi.org/10.23887/jjpgsd.v2i1.2058.

Hamdani, D., Eva, K., \& Indra, S. (2012). Pengaruh Model Pembelajaran Generatif Dengan Menggunakan Alat Peraga Terhadap Pemahaman Konsep Cahaya Kelas VIII DI SMP Negeri 7 Kota Bengkulu. EXACTA.

Hidayati, Y. M. (2012). Pembelajaran Penjumlahan Bilangan Pecahan Dengan Metode Contextual Teaching and Learning $(\mathrm{Ctl})$ Di Sd Muhammadiyah Program Khusus, Kota Barat, Surakarta. Jurnal Penelitian Humaniora, 13(1), 86-94. https://doi.org/https://doi.org/10.23917/humaniora.v13i1.919.

Juliyanti, A., \& Pujiastuti, H. (2017). Pengaruh Kecemasan Matematis dan Konsep Diri terhadap Hasil Belajar Matematika Siswa. Refleksi Edukatika: Jurnal Ilmiah Kependidikan, 7(2). https://doi.org/http://dx.doi.org/10.31000/prima.v4i2.2591.

Laily, A., Jalal, F., \& Karnadi, K. (2019). Peningkatan Kemampuan Konsep Matematika Awal Anak Usia 4-5 Tahun melalui Media Papan Semat. Jurnal Obsesi, 3(2). https://doi.org/https://doi.org/10.31004/obsesi.v3i2.214.

Lisma, E., Rahmadhani, R., \& Siregar, M. A. P. (2019). Pengaruh Kecemasan Terhadap Minat Belajar Matematika Siswa. ENLIGHTEN, 2(2). https://doi.org/https://doi.org/10.32505/enlighten.v2i2.1345.

Made Rika Mulasari, I G A. Ayu Wulandari, M. P. (2020). Model Pembelajaran Means Ends Analysis Terhadap Hasil Belajar Matematika Siswa SD. Jurnal Pedagogi Dan Pembelajaran, 3(3). https://doi.org/http://dx.doi.org/10.23887/jp2.v3i3.25812.

Mirnawati, M., \& Basri, M. (2018). Pengaruh Kecerdasan Emosional Terhadap Hasil Belajar Matematika Siswa Sekolah Dasar. JRPD (Jurnal Riset Pendidikan Dasar), 1(1). https://doi.org/https://doi.org/10.26618/jrpd.v1i1.1240.

Munirah, M., \& Ahmad Putri, S. S. (2018). Pengaruh Kecerdasan Emosional Terhadap Hasil Belajar Matematika Peserta Didik. AULADUNA: Jurnal Pendidikan Dasar Islam, 5(2). https://doi.org/https://doi.org/10.24252/auladuna.v5i2a2.2018.

Nisrina, Ajeng, D. (2018). Hubungan Antara Kecerdasan Emosional Dengan Prestasi Belajar Matematika Siswa Kelas IV SD Negeri Kutabumi IV Kabupaten Tanggerang. Jurnal Taman Cendekia, 2(2), 198. https://doi.org/http://dx.doi.org/10.30738/tc.v2i2.2950. 
Nisrina, A. N., Rini, C. P., \& Latifah, N. (2018). Hubungan Antara Kecerdasan Emosional Dengan Prestasi Belajar Matematika Siswa Kelas Iv Sd Negeri Kutabumi IV Kabupaten Tangerang. Taman Cendekia: Jurnal Pendidikan Ke-SD-An, 2(2). https://doi.org/https://doi.org/10.30738/tc.v2i2.2950.

Nofrialdi, I., Maison, M., \& Muslim, M. (2018). Tingkat Kecemasan Matematika Siswa SMA Negeri 2 Kerinci Kelas X MIA Sebelum Menghadapi Tes Matematika Berdasarkan Gender dan Hubungannya dengan Hasil Belajar. Edumatika: Jurnal Riset Pendidikan Matematika, 1(2). https://doi.org/https://doi.org/10.32939/ejrpm.v1i2.248.

Nofrialdi, Irel, Maison, M., \& Muslim, M. (2018). Tingkat Kecemasan Matematika Siswa SMA Negeri 2 Kerinci Kelas X MIA Sebelum Menghadapi Tes Matematika Berdasarkan Gender dan Hubungannya dengan Hasil Belajar. EDUMATIKA, 1(2). https://doi.org/https://doi.org/10.32939/ejrpm.v1i2.248.

Novikasari, I. (2017). Hubungan Antara Prestasi Belajar Dan Tingkat Kecemasan Matematika Pada Mahasiswa Calon Guru Sd/Mi. Jurnal Aksioma, 5(2). https://doi.org/https://doi.org/10.24127/ajpm.v5i2.671.

Nurfitriyanti, M. (2017). Pengaruh Model Pembelajaran Kooperatif Tipe Jigsaw Terhadap Hasil Belajar Matematika ditinjau dari Kecerdasan Emosional. Formatif: Jurnal $\begin{array}{lll}\text { Ilmiah Pendidikan } & \text { MIPA, }\end{array}$ https://doi.org/https://doi.org/10.30998/formatif.v7i2.2229.

Nurrahmi, A., Witri, G., \& Syahrilfuddin. (2019). Hubungan Antara Kecemasan Dengan Hasil Belajar Matematika Siswa Kelas V Sekolah Dasar Negeri 164 Pekanbaru. Jurnal Pajar (Pendidikan Dan Pengajaran), 3(4). https://doi.org/https://doi.org/10.33578/pjr.v3i4.7354.

Pamungkas, A. S. (2015). Kontribusi Self Concept Matematis Dan Mathematics Anxiety Terhadap Hasil Belajar Mahasiswa. Jurnal Dinamika Pendidikan, 8(2). https://doi.org/https://doi.org/10.33541/jdp.v8i2.114.

Prafitriani, S., Umanailo, M. C. B., Indrayani, N., Lisaholit, S., \& Chamidah, D. (2019). Pengaruh Kecerdasan Emosional terhadap Hasil Belajar Matematika Siswa Kelas VII SMP Negeri 9 Buru. Jurnal Penelitian Pendidikan Matematika, 6(2). https://doi.org/https://doi.org/10.36709/jppm.v6i2.9121.

Rosmiati, U., \& Lestari, P. (2021). Inovasi Model Pembelajaran PBI ( Problem Based Instruction ) Berbasis Whatsapp Sebagai Langkah Solutif Pembelajaran di Masa Pandemi Covid-19. JNPM (Jurnal Nasional Pendidikan Matematika), 5(1), 188-197. https://doi.org/http://dx.doi.org/10.33603/jnpm.v5i1.3708 Inovasi.

Setiadi, Y. (2018). Hubungan Konsep Diri, Kecerdasan Emosional, dan Kecemasan Belajar dengan Prestasi Belajar Mahasiswa. JNPM (Jurnal Nasional Pendidikan Matematika), 2(1). https://doi.org/https://doi.org/10.33603/jnpm.v2i1.1066.

Setyawan, A. A., \& Simbolon, D. (2018). Pengaruh Kecerdasan Emosional Terhadap Hasil Belajar Matematika Siswa Sekolah Dasar. JPPM (Jurnal Penelitian Dan Pembelajaran Matematika),

l(1). https://doi.org/https://doi.org/http://dx.doi.org/10.30870/jppm.v11i1.2980.

Supardi. (2010). Pengaruh Konsep Diri, Sikap Siswa Pada Matematika Dan Kecemasan Siswa Terhadap Hasil Belajar Matematika. Cakrawala Pendidikan, 3(1). https://doi.org/https://doi.org/10.21831/cp.v3i3.362.

Supriyanto, D. H. (2021). Analisis Pengaruh Kecerdasan Emosional Terhadap Proses Berfikir Siswa Kelas IV dalam Memecahkan Masalah Matematika. Jurnal Pendidikan Modern, 6(2). https://doi.org/https://doi.org/10.37471/jpm.v6i2.208.

Wulandari, \& Agustika. (2018). Pengaruh Gaya Kognitif Terhadap Hasil Belajar Matematika Pada Mahasiswa Semester IV Jurusan PGSD UPP Denpasar Universitas Pendidikan 
Ganesha Tahun Ajaran 2016/2017. Jurnal Ilmiah Sekolah Dasar, 2(1). https://doi.org/https://doi.org/10.23887/jisd.v2i1.15515.

Wulandari, F., \& Rakhmawati, R. (2019). Analisis Kemampuan Pemahaman Relasional Matematis: Dampak Strategi Pembelajaran Index Card Match. Desimal: Jurnal Matematika, 2(3), 203-209. https://doi.org/https://doi.org/10.24042/djm.v2i3.4291.

Yaya Setiadi. (2018). Hubungan Konsep Diri, Kecerdasan Emosional, dan Kecemasan Belajar dengan Prestasi Belajar Mahasiswa. JNPM (Jurnal Nasional Pendidikan Matematika), 2(1). https://doi.org/http://dx.doi.org/10.33603/jnpm.v2i1.1066. 